AL IBTIDA: JURNAL PENDIDIKAN GURU MI (2020) Vol 7 (2) : 179-196

DOI: http://dx.doi.org/10.24235/al.ibtida.snj.v7i2.6676

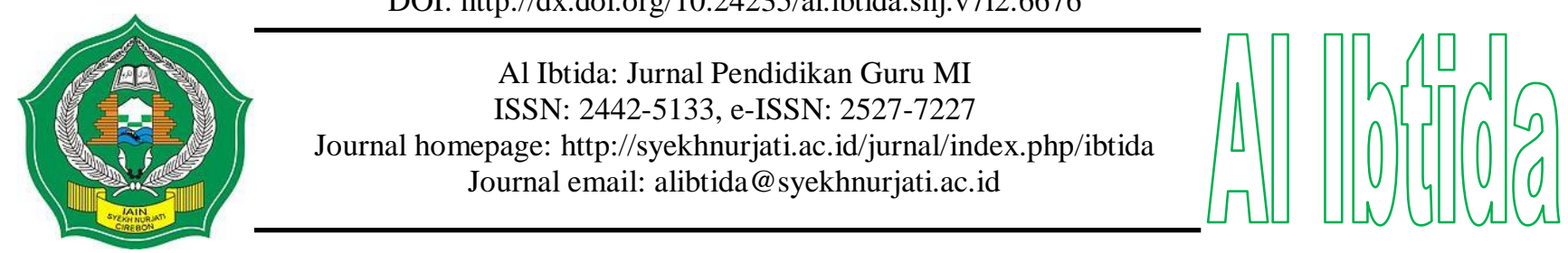

\title{
Developing Edutainment-Based Comic Media in Integrative-Thematic Learning in the Elementary School
}

\author{
Rani Febriyanti* \\ *Department of Basic Education, Postgraduate Program, \\ Universitas Negeri Yogyakarta, Indonesia \\ Email: ranifebriyanti.2018@student.uny.ac.id \\ Ali Mustadi** \\ **Department of Basic Education, Postgraduate Program, \\ Universitas Negeri Yogyakarta, Indonesia \\ Email: ali_mustadi@uny.ac.id
}

Received: July $09^{\text {th }}, 2020$. Accepted: September $17^{\text {th }}, 2020$. Published: October $29^{\text {th }}, 2020$.

\begin{abstract}
The aim of this research is to develop edutainment-based comic media in thematicintegrative learning in fifth grade of elementary school. This study is a Research and Development (R\&D) using the Borg and Gall model. The data were obtained through observation, interviews, and questionnaires. The results of comic media were obtained through a media expert product evaluation questionnaire and material from experts, educational practitioners, and peers. While the trial results were obtained through a questionnaire response given to 72 fifth grade elementary school students. The results of the validators indicate that the comic media is very feasible to be seen from the aspect of the media with an average is $92,27 \%$, it is also considered very feasible from the aspect of the material with an average is $91,63 \%$. Validation results with education practitioners get an average of $81,5 \%$ and $87,82 \%$ for peers with the criteria very good. The results of small class trial get an average is $84,72 \%$ and large class trial get an average of $91,6 \%$ with very good criteria. It also obtained an average is $91,6 \%$ from the teachers' response questionnaire with criteria very good. Based on the results, the edutainment-based comic media is very feasible for SD/MI teacher to be used in integrative thematic learning. Most students believed that comics contribute to facilitate understanding of the concept of the material and provide fun for students in reading.
\end{abstract}

Keywords: comic media, edutainment, integrative-thematic learning. 


\begin{abstract}
Abstrak
Penelitian ini bertujuan untuk mengembangkan media komik berbasis edutainment dalam pembelajaran tematik-integratif di kelas V Sekolah Dasar. Penelitian ini merupakan penelitian pengembangan dengan menggunakan model Borg and Gall. Data penelitian ini diperoleh melalui observasi, wawancara, dan angket. Hasil kelayakan media komik berbasis edutainment diperoleh melalui angket penilaian produk ahli media dan ahli materi, guru kelas, dan teman sejawat. Sedangkan hasil uji coba diperoleh melalui angket respon yang diberikan kepada 72 siswa kelas V SD. Hasil validasi ahli menunjukkan bahwa media komik berbasis edutainment sangat layak dilihat dari aspek media dengan rata-rata 92,27\% dan aspek materi dengan rata-rata $91,63 \%$. Hasil validasi oleh praktisi pendidikan mendapatkan ratarata $81,5 \%$ dan penilaian teman sejawat mendapatkan rata-rata $87,82 \%$ dengan kriteria sangat baik. Hasil uji coba kelas kecil mendapatkan rata-rata $84,72 \%$ dan uji coba kelas besar memperoleh rata-rata 91,6\% dengan kriteria sangat baik. Guru juga merespon sangat baik terhadap media komik berbasis edutainment dengan memperoleh rata-rata $91.6 \%$. Sehingga dapat disimpulkan bahwa media komik berbasis edutainment sangat layak digunakan dalam pembelajaran tematik-integratif di sekolah dasar. Banyak siswa yang meyakini bahwa komik mampu memfasilitasi pemahaman konsep materi dan memberikan kesenangan dalam membaca.
\end{abstract}

Kata kunci: media komik, edutainment, pembelajaran tematik-integratif.

\title{
INTRODUCTION
}

The effectiveness of teaching can be achieved in various ways, one of which is by using appropriate teaching materials and learning media. A number of studies have stated that learning media affect student learning (Enteria \& Casumpang, 2019; Kurniawati, Wahyuni, \& Putra, 2017; Muzumdar, 2016). The use of media can also enhance the quality of learning process that can improve the quality of learning outcomes (Munawwaroh, Priyono, \& Ningsih, 2018; Sanaky, 2013). In planning the learning process and the selection of learning media, it must consider the characteristics of students to teach (Indaryati \& Jailani, 2015). Based on Piaget's development stage, the characteristics of elementary school students aged 7-12 years are included in the concrete operational stage (Budiarti \& Haryanto, 2016), in which at this stage, students more easily understand the materials if it was given a concrete object directly (Nugraheni, 2017). At this stage, students also prefer for choosing an interesting objects. Fifth-grade elementary school students at the age of 10-11 years and they are starting to be able to generate thoughts towards abstract thinking. In this transition period, students need media that can help them to think abstractly, logically, and complexly (Santrock, 2013).

There are modern teaching methods that can be used in the learning process, which is the use of non-electronic materials, such as comics (Enteria \& Casumpang, 2019; Kurniawati et al., 2017). Comic media can make students enjoy reading activities (Kurniawati et al., 2017; Morrison, Bryan, \& Chilcoat, 2002) and it can bridge understanding of the text that is 
read is more complex (Vulte, 2013). The comic is a book-formed media that presents a story by integrating two media, consisting of words and drawings (Azman, Zaibon, \& Shiratuddin, 2014; Jee \& Anggoro, 2012). Comics as one of the teaching materials can facilitate students in learning material concepts thoroughly, such as cognitive development, motivation, and information processing (Cho, 2012; Enteria \& Casumpang, 2019; Jee \& Anggoro, 2012; Ertuğrul Özdemir, 2017). Comic media can even improve scientific literacy and student performance in certain concepts (Enteria \& Casumpang, 2019; Jee \& Anggoro, 2012; Toh, Tin, Cheng, Ho, Jiang, \& Lim, 2017).

Education in Indonesia is currently using the curriculum 2013 with thematicintegrative learning. It is combines several subjects into one theme. The aim is to enable students to actively explore and discover concepts and scientific principles in a holistic, meaningful and authentic manner, both individually and in groups (Toh, Tin et al., 2017). In the curriculum 2013, the approach used is a scientific approach which includes observation, questioning, reasoning, trying, and communicating activities (Hidayat \& Rostikawati, 2018). However, the problem that is often encountered in thematic-integrative learning is the lack of teaching materials used in learning so that the teachers are only focused on one teaching material, which is teachers' and students' textbooks that have been provided by the government (Resti \& Alizamar, 2019; Saputro \& Soeharto, 2015). Moreover, the materials in students' textbooks, such as examples and detailed reviews of the materials, are incomplete so the teachers must be active in explaining and developing additional materials from various sources (Handayani, 2018).

Based on the results of observations and interviews with fifth grade teachers of SD Negeri Kentungan (State Elementary School of Kentungan) and SD Negeri Bhakti Karya (State Elementary School of Bhakti Karya), the teachers acknowledge that, in terms of visuals, the textbooks provided by the government are good enough because they are interesting and some materials have been provided with pictures. It can make material easier for students to understand. However, the materials in the textbooks are limited and do not provide an in-depth explanation. Therefore, the school regulates a policy to provide additional hours for study after school to provide materials that are not taught during the learning process. In addition, based on observations, teachers tend to use lectures, question and answer methods and one in a while use media in learning. The students conveyed that it is difficult to understand the material in the textbooks due to incomplete material and sometimes students feel that they do not really understand the materials, while they must switch to other subjects 
because one of the characteristics of thematic learning is to integrate several subjects into one theme. So that media and other sources are needed to add information related to the material.

The most appropriate and effective approach to teaching and learning as a renewal in education is an approach that covers suitability between situations and children's learning with real-life situations in the environment (Hwang, Yang, \& Wang, 2013). Thus, the comics developed are those that associate materials with everyday life, completed with concrete drawings that help students to understand the material. The comic will be used is based on edutainment, in which the term is derived from the words of education and entertainment (Ardani \& Setyaningrum, 2018). It means the teaching and learning process is carried out in an environment that is not serious but fun (Isa et al., 2015).

The edutainment' method has been developed to provide information effectively through various entertainment media, for example, print works, electronic interactive applications, and performing arts, such as improvised theaters. Besides, the edutainment method is proven as an approach that can be comprehending, interesting, arousing emotions, and persuasive, which in some cases can be beneficial for providing information to the public (Cirigliano, 2012). Whereas in learning, the edutainment method can improve student learning outcomes, student activities (Anggarniastiti, Rosana, \& Setianingsih, 2017; Berman, Wiyono, Zakaria, \& Supriatno, 2019; Putra, 2018) and edutainment media can help to arouse students' curiosity (Ardani \& Setyaningrum, 2018). From the characteristics of edutainment method is fun, comic media in the form of pictorial media can make students happy when they see colored pictures and fun activities such as drawing and playing traditional games found in this comic media. This is in accordance with the characteristics of elementary school students who like interesting and colorful pictures as they find in illustration in comic (Rosyida, Mustaji, \& Subroto, 2018).

Many studies have revealed the benefits of comic media in learning. Lin, Lin, Lee, \& Yore (2015) stated that comic media can increase students' interest and enjoyment in learning while textbooks can reduce students' interest and enjoyment in reading. Furthermore, Ertugrul Özdemir \& Eryilmaz (2019) also stated that science comic media can help learning become fun. It makes classroom management to be easier. Dallacqua (2020) in his research also said that comic media has been positioned as an attractive support for readers and has the potential to increase knowledge of the content being taught. Another study by Kim, Chung, Jang, \& Chung, (2017) which stated that the learning outcomes of students who use educational anatomy comics are significantly higher than students who do not use educational anatomy comics. Educational anatomy comics can increase student's interest and understanding of 
basic anatomy. In addition, Zagkotas (2019) also states that the use of comic media in everyday life can make learning more interesting, but teachers also need to start creative and effective teaching so that learning with comic media can achieve learning goals. This is also in line with Cho (2012) research that through teacher guidance, comics can bridge students to foster students' motivation and interest in reading.

Referring to previous research and problems that occurred at SDN Kentungan and SDN Bhakti Karya, it is necessary to develop learning media to increase students' reading interest and concepts understanding. Therefore, researchers are encouraged to carry out research and development of comics based on edutainment in thematic-integrative learning in fifth grade elementary school. In contrast to previous studies, this study combines edutainment-based learning where in learning students do not only read comic books but do fun activities such as singing, drawing, and playing traditional games which will be contained in edutainment-based comic media so that students are not only reading interest has increased, but through direct experience students can more easily interpret and understand the material presented.

Based on the description above, this research focus is to develop a media through comic based on edutainment and to find out the feasibility of the media in thematic-integrated learning in fifth grade elementary school. The results of this study are expected to contribute in helping teachers obtain the additional information and convey the stability of the material. In addition, it can provide innovation for teachers in learning media. Then, for students, comics as a companion media are expected to be able to help students understand the concept of material appropriately so that the learning process can attract students and be fun for them and can attract student's reading interest.

\section{METHODS}

This study used development research with Borg and Gall model, which has ten steps in product development (Borg \& Gall, 1983). But in this case, it will reach the seventh step. The researcher only focus on the feasibility and how students respond to product development.

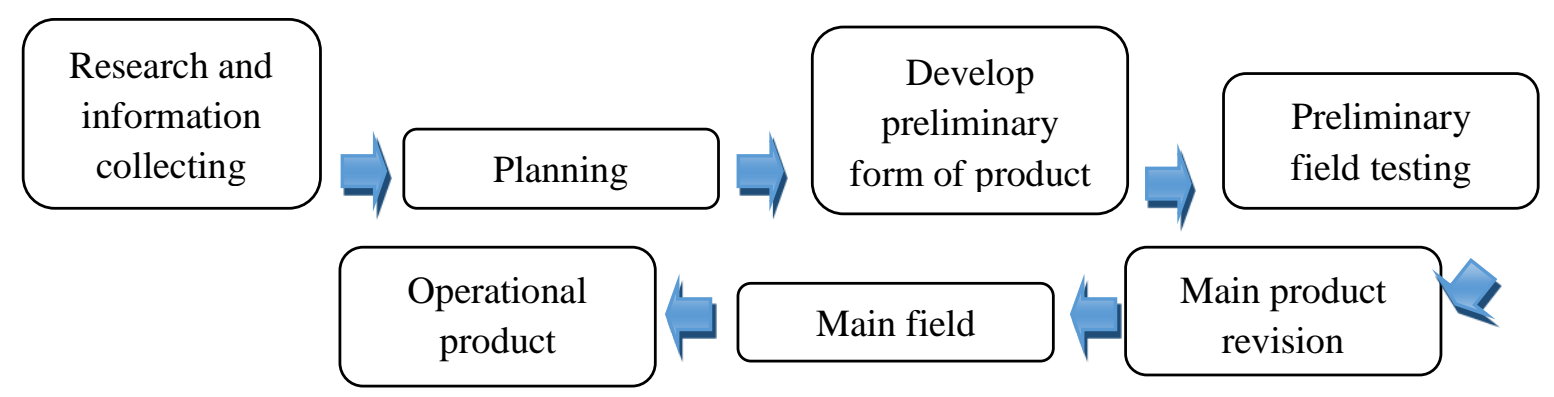

Figure 1. Borg and Gall Model 
The research procedure involves seventh step, including (1) research and information collection, (2) planning (designing product concepts and creating storyboards), (3) develop preliminary form of product (product development based on the storyboards, media feasibility, and revisions), (4) Preliminary field of testing (implementing the comic media products, then teachers and students give responses to the edutainment-based comic media), (5) Main product revision (evaluating and revising the comic products based on the results of the students' and teachers' response questionnaire), (6) Main field of testing (implementation the comic media product), (7) Operational product revision (evaluating and revising the comic product).

The subjects in this study were experts, education practitioners, peer reviews and students. The feasibility of comic media was assessed by 1 material expert and 1 media expert, 3 education practitioners, and 4 peers of review. The questionnaire response was provided for 2 teachers and 50 fifth grade students of SDN Kentungan (State Elementary School of Kentungan) and SDN Bhakti Karya (State Elementary School of Bhakti Karya), Sleman, Yogyakarta, on the application of comic media. The data collection techniques used observation, interviews, scales and questionnaires. The instruments used were observation sheets, teachers' and students' interview sheets, material experts' validation sheets, media experts' validation sheets, and teachers' and students' response questionnaires.

The observation and interview sheets were used as a data collection analysis. The material and media experts' validation sheets were used to assess the feasibility of comic media products that had previously been declared eligible for use. While the teachers' and students' response questionnaire was used to obtain responses from teachers and students to the developed comic media. The teachers' and students' questionnaire response used was previously assessed and declared to be suitable for use by the instrument experts. Data analysis techniques using is qualitative descriptions that contain the results of product development and assessment by experts, educational practitioners, peer reviews, and students' responses to the product. The calculation results are converted into percentages $(\mathrm{P})$ with very good criteria $(\mathrm{P}>80 \%)$, good $(60 \%<\mathrm{P}<80 \%)$, fair $(40 \%<\mathrm{P}<60 \%)$, inadequate $(20 \%<\mathrm{P}$ $<40 \%$ ), and inacceptable ( $<20 \%)$ (Anggraheni, Hidayah, \& Shawmi, 2019).

\section{RESULTS AND DISCUSSION}

\section{. Research and Information Collecting Stage}

This stage was carried out to identify and analyze the learning conditions required in the development of comic media. The analysis stage was done by conducting observations and interviews with schools to obtain information related to the implementation of thematic 
learning. Based on observations and interviews with fifth-grade elementary school teachers conducted in 2 elementary schools in the class VI of Depok, Sleman, it was found that the teachers had carried out thematic learning well. However, sometimes teachers need complementary teaching materials besides textbooks that have been provided by the government. Visually, the textbooks used are quite interesting. However, for the teachers, the materials in the textbooks are limited and do not provide an in-depth explanation. Therefore, the school regulates a policy to provide additional study hours after school to provide materials that are not taught during the learning process. According to the teachers, this is an agreement made among parents, the principal and the teachers for the achievement of learning goals.

In addition, teachers tend to use lectures, question and answer methods and rarely use media in learning. The students conveyed that it is difficult to understand the material in the textbooks due to incomplete material and sometimes students still feel that they do not really understand the materials.T hey must switch to other subjects because one of the characteristics of thematic learning is to integrate several subjects into one theme. Hence, the development of complementary media in the form of edutainment-based comic media was developed to assist and facilitate students in understanding the materials and increase students' knowledge besides the use of the existing textbooks. By using edutainment-based comic media, it will help teachers and students in an interesting and fun learning process.

\section{Planning Stage}

The planning stage includes the activities of designing the lesson plan, learning material (storyline), and learning media (storyboard).

\section{Lesson Plan (RPP)}

The initial step in the design stage was to plan how the learning process would be carried out using comic media. The RPP would be designed according to the 2013 curriculum. The RPP draft contained the identity of the learning unit, Core Competencies (KI), Basic Competencies $(\mathrm{KD})$, learning indicators, teaching materials, learning methods and models, learning tools and materials, learning activities, time allocation, and assessment of learning. The topic used was the Theme 8 (Humans and Environments), Sub-theme 1 (Environment as Our Best Friend) with limited material on the Natural Science (Water Cycle), Social Science (Economic Role in Social and Culture), and Civic Education (Socio-cultural Diversity). Thereby, 6 lesson plans were designed and integrated with subjects that were relevant to the basic competency of the learning. The learning process was also designed using a scientific 
approach (observing, asking, collecting data, associating, and communicating) that was adjusted to the characteristics of thematic learning as shown in Figure 2.
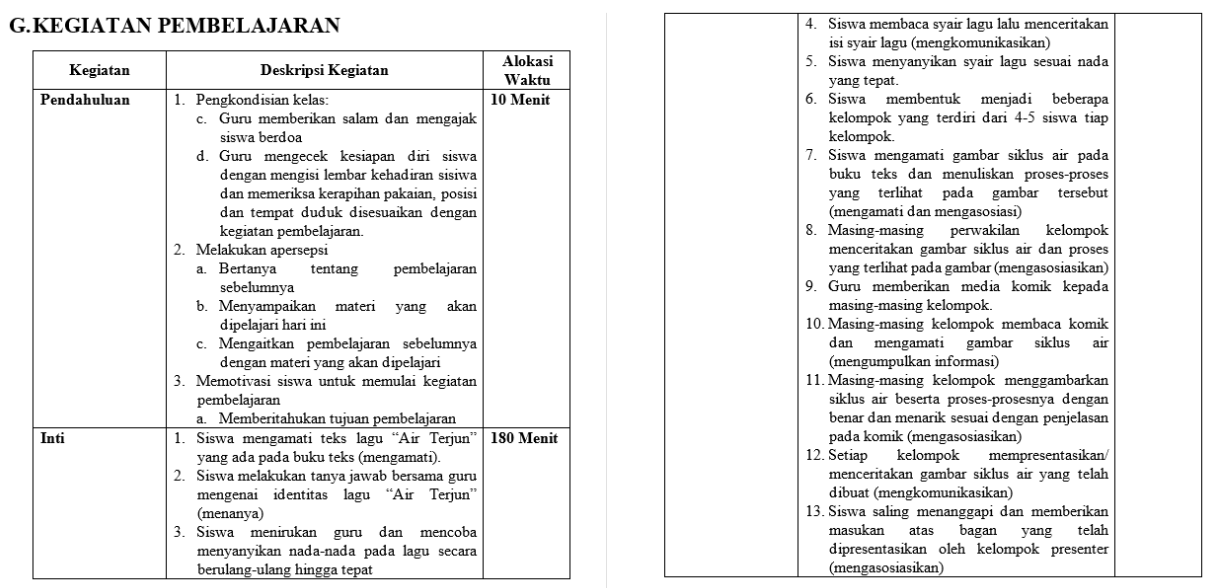

Figure 2. Design of Learning Activities in RPP

\section{Learning materials}

The learning materials developed were Natural Science (Water Cycle Material), Social Science (Economic Role in Social and Culture Material), and Civic Education (Socio-cultural Diversity Material) on Theme 8, Humans and the Environment, Sub-theme 1, Environment as Our Best Friend.

The learning material was transformed in comic media through conversations between characters in the comic. In addition, the material was reaffirmed with concrete drawings that supported the materials to make it easier for students to understand the materials and attract students' interest in reading comic media. At the end of learning process, a task was given to students both individually and in groups to determine learning achievement. The design of learning material developed in comic media was made in the form of a storyline before being incorporated into the comic story shown in figure 3.

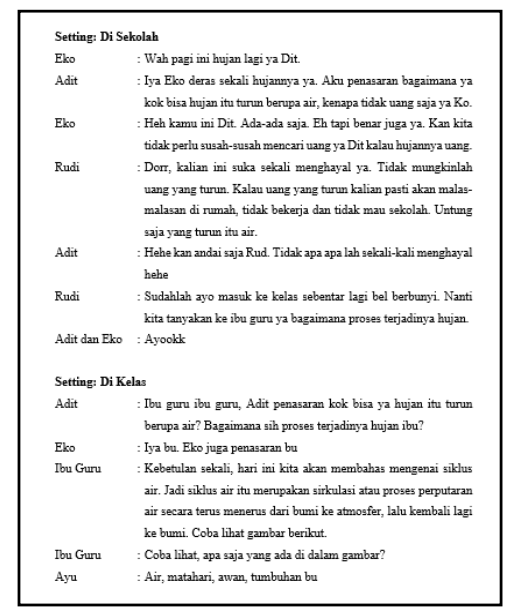

Figure 3. Design of Teaching Material 


\section{Learning Media}

The learning media developed in this study were edutainment-based comic media using Corel Draw Application. The comic media contain with text and drawings, but the difference is themedia contains learning material can be used as a complementary book in elementary school learning, especially in the fifth grade. The comic media consists of 3 main parts, consisting of (1) the title page section, including the front cover, identity, preface, table of contents, introduction of characters, instruction for reading comics, and Mapping of KI and $\mathrm{KD}$, (2) the contents page section, including 6 lessons, which are (a) Water function: What is the importance of water for life?, (b) Water cycle: Where does rainwater come from?, (c) Indonesian Culture: The beautiful culture of my country, (d) Types of business: I want to be a teacher, (e) Water cycle: Why does the water in a river dry?, (f) Let's play!, and evaluation questions, and (3) back cover page section, including summary, bibliography, developer profiles and back cover. The comic media design was made in the form of a storyboard before being inserted into the comic story shown in Figure 4.

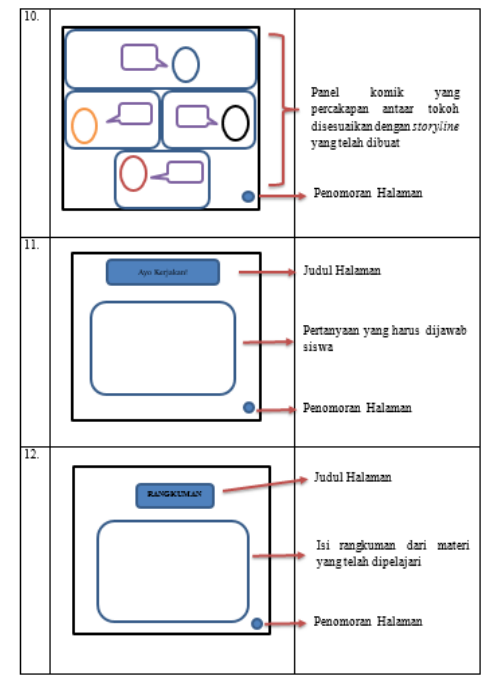

Figure 4. Design of Learning Media

\section{Develop Preliminary Form of Product Stage}

The development of comic media was based on storylines and storyboards that were designed in the previous stage. The development of the comic was carried out using the CorelDraw 2018 application with the XP-Pen tablet which can be seen in Figure 5 until 8. 


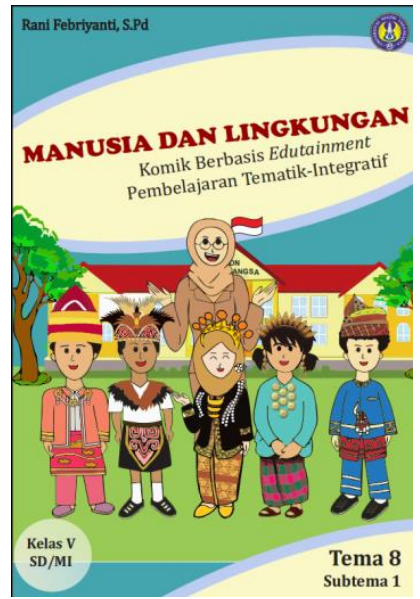

Figure 5. Cover of Comic Media
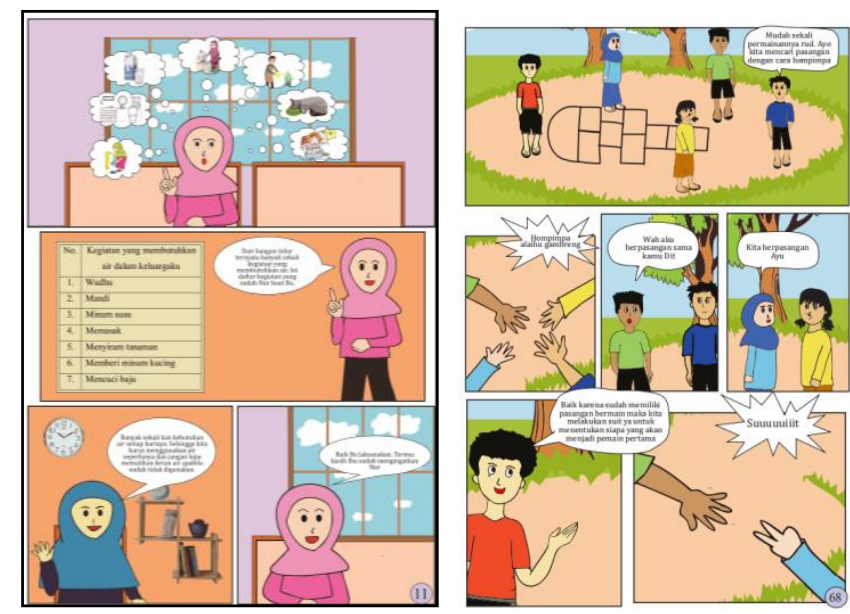

Figure 6. Content of Comic Media

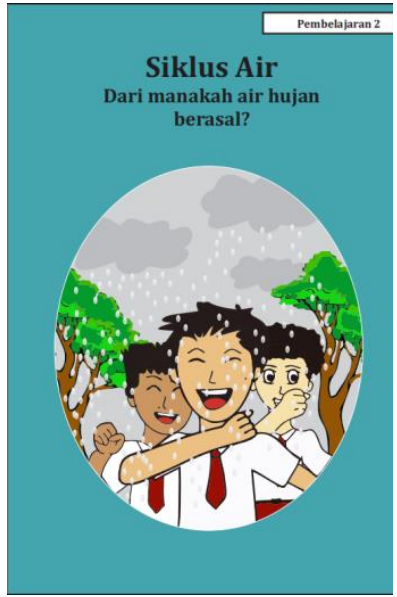

Figure 7. Cover of Comic

Media Subthemes
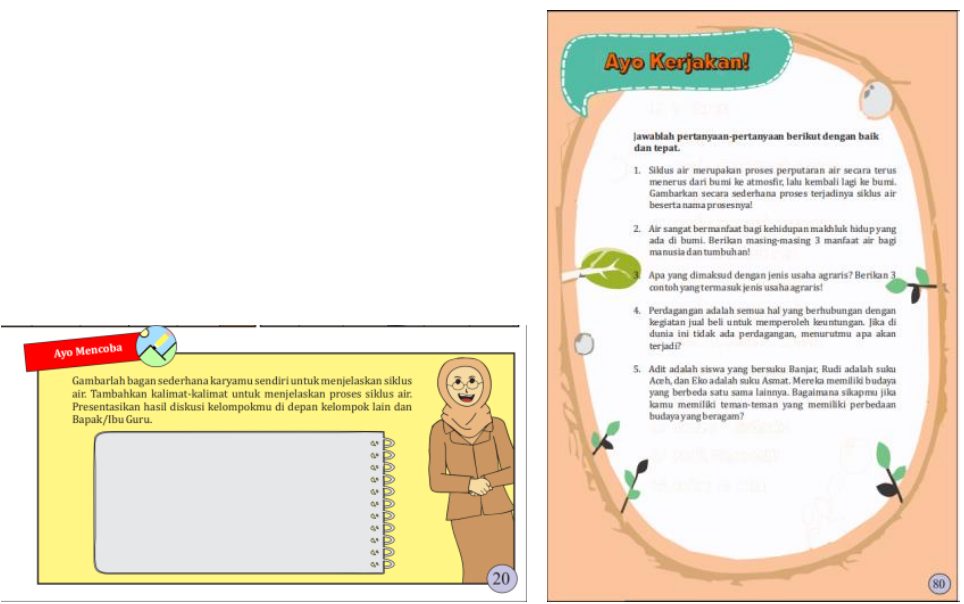

Figure 8. Practice dan Exercise

The feasibility of the comic have been designed are then assessed by experts, educational practitioners and peer reviews. The assessment of media and comic material was carried out using a product validation scale sheet. Comments and suggestions provided by the validators were used as revision material of the comic products. It goes into very good criteria which can be seen in Table 3 below.

Tabel 3. Assessment of Material Expert

\begin{tabular}{cll}
\hline No. & Aspects & Pecentage \\
\hline 1 & Valid & $96 \%$ \\
2 & Level of Importance & $92 \%$ \\
3 & Learnability & $80 \%$ \\
4 & Attract Interest & $93,33 \%$ \\
5 & Usefulness & $100 \%$ \\
\hline & Average & $92,27 \%$ \\
\hline
\end{tabular}


Based on table 3, the results of the material feasibility assessment are in the aspect of valid get $96 \%$ results, the level of important aspect get $92 \%$, the acceptability aspect get $80 \%$, the attract interest aspect get 93,33\%, and the usefulness aspect get 100\%. Then, the assessment of the feasibility of learning media can be seen in Table 4 below.

Table 4. Assessment of Media Expert

\begin{tabular}{cll}
\hline No. & Aspects & Percentage \\
\hline 1 & Consistency & $88 \%$ \\
2 & Balance & $100 \%$ \\
3 & Visual Color & $80 \%$ \\
4 & Easy to Read & $90 \%$ \\
5 & Visual Attractiveness & $95 \%$ \\
6 & Text Style & $100 \%$ \\
7 & Text Size & $100 \%$ \\
8 & Text Color & $80 \%$ \\
\hline & Average & $91,63 \%$ \\
\hline
\end{tabular}

Based on table 4 above, the results of media feasibility assessment are in the aspect of consistency get $88 \%$, the balance aspect get $100 \%$, the visual color aspect get $80 \%$, the easy to read aspect get $90 \%$, the visual attractiveness aspect get $95 \%$, the text style aspect get $100 \%$, the text size aspect get $100 \%$, and the text color aspect get $80 \%$. If it is averaged from the total, all the assessments get $91.63 \%$ and classified into very good criteria. Moreover, there are three educational practitioners whom participate in providing assessment and suggestion for this study. The difference of the three education practitioners can be seen in table 5 .

Table 5. Results of Educational Practitioner's Assessment

\begin{tabular}{clllll}
\hline \multirow{2}{*}{ No. } & \multirow{2}{*}{ Aspects } & \multicolumn{3}{c}{ Education Practitioner } & \multirow{2}{*}{ Percentage } \\
\cline { 3 - 5 } & I & II & III & \\
\hline 1 & Consistency & $98 \%$ & $82 \%$ & $88 \%$ & $89,3 \%$ \\
2 & Balance & $93,3 \%$ & $80 \%$ & $93,3 \%$ & $88,9 \%$ \\
3 & Visual Color & $100 \%$ & $86,7 \%$ & $93,3 \%$ & $93,3 \%$ \\
4 & Easy to Read & $100 \%$ & $80 \%$ & $95 \%$ & $91,7 \%$ \\
5 & Visual Attractiveness & $100 \%$ & $90 \%$ & $95 \%$ & $95 \%$ \\
6 & Text Style & $100 \%$ & $70 \%$ & $100 \%$ & $90 \%$ \\
7 & Text Size & $100 \%$ & $70 \%$ & $80 \%$ & $83,3 \%$ \\
8 & Text Color & $100 \%$ & $90 \%$ & $100 \%$ & $96,7 \%$ \\
9 & Valid & $95 \%$ & $80 \%$ & $100 \%$ & $93,3 \%$ \\
10 & Level of Importance & $93,3 \%$ & $93,3 \%$ & $100 \%$ & $94,7 \%$ \\
11 & Learnability & $80 \%$ & $88 \%$ & $100 \%$ & $89,3 \%$ \\
12 & Attract Interest & $93,3 \%$ & $93,3 \%$ & $93,3 \%$ & $93,3 \%$ \\
13 & Usefulness & $100 \%$ & $80 \%$ & $90 \%$ & $90 \%$ \\
\hline & Average & \multicolumn{3}{c}{} & $91,5 \%$ \\
\hline
\end{tabular}

The assessment of three education practitioners were combine and obtained an average of the thirteen aspects is $91,5 \%$ and it goes into very good criteria. In addition, there are five 
peer reviewers whom participate in providing assessment. The difference of the five peer reviews can be seen in table 6 below.

Table 6. Results of Peer Reviews Assessment

\begin{tabular}{|c|c|c|c|c|c|c|c|}
\hline \multirow{2}{*}{ No. } & \multirow{2}{*}{ Aspects } & \multicolumn{3}{|c|}{ Peer Review } & \multirow[b]{2}{*}{ IV } & \multirow[b]{2}{*}{$\mathbf{V}$} & \multirow{2}{*}{ Percentage } \\
\hline & & I & II & III & & & \\
\hline 1 & Consistency & $92 \%$ & $92 \%$ & $74 \%$ & $92 \%$ & $86 \%$ & $87,2 \%$ \\
\hline 2 & Balance & $80 \%$ & $93,33 \%$ & $73,33 \%$ & $93,33 \%$ & $100 \%$ & $88 \%$ \\
\hline 3 & Visual Color & $86,67 \%$ & $86,67 \%$ & $86,67 \%$ & $93,33 \%$ & $80 \%$ & $86,67 \%$ \\
\hline 4 & Easy to Read & $90 \%$ & $90 \%$ & $100 \%$ & $95 \%$ & $75 \%$ & $87 \%$ \\
\hline 5 & Visual Attractiveness & $85 \%$ & $90 \%$ & $80 \%$ & $100 \%$ & $75 \%$ & $88 \%$ \\
\hline 6 & Text Style & $90 \%$ & $90 \%$ & $100 \%$ & $80 \%$ & $80 \%$ & $82 \%$ \\
\hline 7 & Text Size & $80 \%$ & $70 \%$ & $90 \%$ & $100 \%$ & $90 \%$ & $90 \%$ \\
\hline 8 & Text Color & $90 \%$ & $100 \%$ & $96 \%$ & $90 \%$ & $90 \%$ & $94 \%$ \\
\hline 9 & Valid & $84 \%$ & $96 \%$ & $100 \%$ & $96 \%$ & $92 \%$ & $93,6 \%$ \\
\hline 10 & Level of Importance & $80 \%$ & $96 \%$ & $88 \%$ & $92 \%$ & $92 \%$ & $89,6 \%$ \\
\hline 11 & Learnability & $84 \%$ & $96 \%$ & $80 \%$ & $84 \%$ & $84 \%$ & $85,6 \%$ \\
\hline 12 & Attract Interest & $80 \%$ & $86,67 \%$ & $80 \%$ & $86,6 \%$ & $86,67 \%$ & $84 \%$ \\
\hline 13 & Usefulness & $80 \%$ & $90 \%$ & $90 \%$ & $90 \%$ & $80 \%$ & $86 \%$ \\
\hline \multicolumn{7}{|c|}{ Average } & $87,82 \%$ \\
\hline
\end{tabular}

Based on table 6 above, the results of assessment five peer reviews were combine and obtained an average of thirteen aspects is $87,82 \%$ and it goes into very good criteria. Overall, the feasibility assessment of experts, class teachers and peer reviews seen from the aspects of media and material can be considered as very good and can be used in the learning process which can be seen in Figure 9. Furthermore, the comic media will be applied in learning in the fifth grade of elementary school and get a response from the fifth-grade elementary school teachers and students.

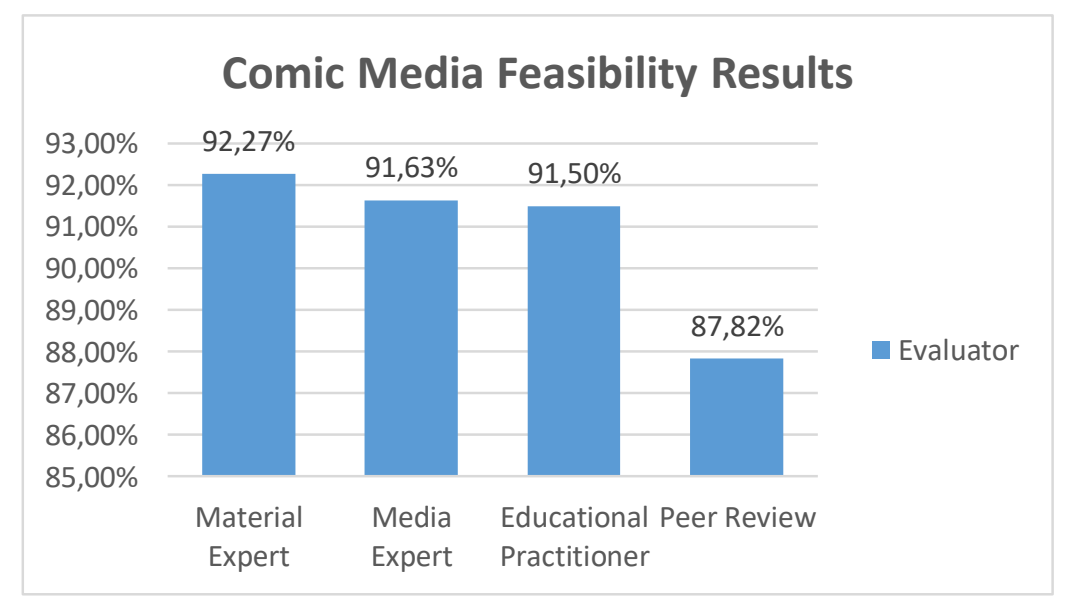

Figure 9. Edutainment-Based Comic Media Feasibility Results 


\section{Implementation Stage}

The comic media had been declared feasible were then tested on students through learning. Questionnaire responses for teachers and students were given after the learning using the comic media was carried out. A trial questionnaire was provided to obtain product quality scores based on assessments given by 3 class teachers and 72 grade fifth of elementary school students. Based on this trial, it would be known the deficiencies of the developed comic media. Comments and suggestions given by teachers and students would be used as a reference for further revisions. The results of which can be seen in Table 7 as follow

Table 7. Result of Analysis of Questionnaire Response of the Fifth Grade Teachers

\begin{tabular}{lllll}
\hline \multirow{2}{*}{ Aspect } & \multicolumn{2}{c}{ Teachers } & \multicolumn{2}{c}{ Percentage } \\
\cline { 2 - 4 } & I & II & III & \\
\hline Suitability with the Curriculum & $100 \%$ & $87,5 \%$ & $75 \%$ & $87,5 \%$ \\
Language & $75 \%$ & $83,33 \%$ & $75 \%$ & $77,78 \%$ \\
Usefulness & $83,33 \%$ & $87,5 \%$ & $100 \%$ & $90,28 \%$ \\
Ease of Use & $87,5 \%$ & $87,5 \%$ & $100 \%$ & $91,67 \%$ \\
Design & $75 \%$ & $83,33 \%$ & $91.67 \%$ & $83,33 \%$ \\
Legibility & $75 \%$ & $100 \%$ & $100 \%$ & $91,67 \%$ \\
Motivate Student & $83,33 \%$ & $100 \%$ & $91,67 \%$ & $91,67 \%$ \\
\hline \multicolumn{4}{l}{} \\
\hline
\end{tabular}

Based on table 7 above, the results of teachers' questionnaire responses were tabulated and obtained an overall average of $87,7 \%$. It can be conclude that comic media was categorized as very good and could be used in learning. The Edutainment-based comic media also passed trials, namely trials of small classes and large classes. This small class trial was conducted on one school with one class, namely SD Negeri Bhakti Karya and large class was conducted one school with two class namely SD Negeri Kentungan Sleman, which can be seen in Table 8 and 9 as follow.

Tabel 8. Percentage of Small Class Test

\begin{tabular}{cc}
\hline Aspect & Small Class \\
\hline Interesting Presentation & $83,93 \%$ \\
Systematic Presentation & $82,14 \%$ \\
Comic Book Graphics & $85,88 \%$ \\
Language & $86,90 \%$ \\
\hline Average & $84,72 \%$ \\
\hline
\end{tabular}

Tabel 9. Percentage of Big Class Test

\begin{tabular}{ccc}
\hline Aspect & Big Class A & Big Class B \\
\hline Interesting Presentation & $89,42 \%$ & $92,25 \%$ \\
Systematic Presentation & $87,50 \%$ & $91,00 \%$ \\
Comic Book Graphics & $84,62 \%$ & $91.14 \%$ \\
Language & $88,94 \%$ & $92,00 \%$ \\
\hline Average & $87,62 \%$ & $91,60 \%$ \\
\hline
\end{tabular}


Based on the results obtained which have been averaged in small class trial, it was found that the response of student to the products reached $84,72 \%$ and the large class trial get $91,60 \%$. It can be conclude that the comic media was categorized as very good and could be used in learning. Thus, the comic media was feasible to be used as a complementary book of learning materials for the fifth grade of Elementary School, especially in Theme 8, Sub-theme 1. It appears that the students had a high interest when the teachers asked them to read the comic.

\section{Product Revision Stage}

The evaluation was based on the results of material expert, media expert, educational practitioner's, peer reviews, teachers and students response questionnaire. Comments and suggestions were given as users of the edutainment-based comic media. Revisions made included the correction of ineffective sentences, the use of Enhanced Spelling (EYD) in conversations, and adjusting drawings to their proper conditions. Figure 10 shows the results of the comic media before the revision and after the revision by adjusting the drawings with a story that depicts cloudy and rainy weather.

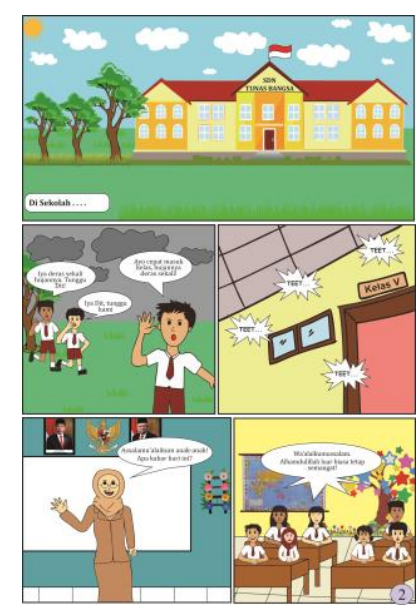

Before Revision

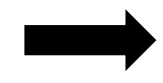

Figure 10. Image Revision Adapted to the Condition in the Story

Based on the results of research and development, edutainment-based comic media developed in thematic-integrative learning in fifth grade elementary schools are concluded to be feasible in the learning process. The edutainment-based comic that was developed contains illustrations of images and text depicting the concepts of natural science, social science, and civic education. Presentation of material concepts through pictures and text can help students understand the concept of the material well (Dallacqua \& Peralta, 2019). The inclusion of drawing illustrations also made the students more enthusiastic in learning and motivated to learn the material (Rahayu \& Kuswanto, 2020; Widyawati \& Prodjosantoso, 2015). 
The material presented is related to students' daily lives accompanied by examples that are easy for students to understand. Ertugrul Özdemir \& Eryilmaz (2019) stated that comics can be made to teach certain concepts as the main learning activity. So that comic media can help students to understand the concept of the material correctly. The use of nonfiction comic media is suggested to obtain the correct knowledge and visualization of the material will be a good tool for communicating material to students (Lin et al., 2015). This is in accordance with the storyline contained in comics based on edutainment, because the material is related to the reality and daily lives of students. The language used in the comic media is also simple and the storyline can provide context to a problem or explanation of a material to help children understand the concept of the material (Cho, 2012; Enteria \& Casumpang, 2019; Lin et al., 2015). Besides, the comic media were also able to increase enjoyment in reading and increase students' reading comprehension (Ertuğrul Özdemir, 2017).

In addition, learning activities are fun (edutainment) in accordance with the characteristics of fifth grade elementary school students, including singing, discussing, drawing, and playing traditional games. Ertugrul Özdemir \& Eryilmaz (2019) found that comics can make a fun learning activity. Through the drawing process, it can be another strategy to improve reading comprehension (Shiang, 2018). In comics based on edutainment, the drawing process carried out the water cycle process which is a concept of natural science material. At the end of each lesson, there is an assignment given to students, both in the form of individuals and groups, the assignment given is based on the material for each learning activity. Students can share perspectives, solve the problems and can draw conclusions with the group (Dallacqua, 2020). Then, at the end of sub-theme, there is a question exercise that aims to test students' understanding of the concept of material taught in sub-theme 1.

\section{CONCLUSION}

Based on the research findings, it can be concluded that edutainment-based comic media as a complementary media very appropriate to be used. It can help teachers in the learning process. The development of edutainment-based comic media on integrative thematic learning in fifth grade has passed the validation form material expert, media expert, education practitioners, peer reviews, teachers, and students. Both teachers and students feel enthusiastic when learning by using edutainment-based comic media. Therefore, the edutainment-based comic media is highly recommended for SD/MI teacher to be used in integrative thematic learning, especially in fifth class, Theme 8 (Humans and Environments), Sub-theme 1 (Environment as Our Best Friend). This research is only limited to the material of natural 
science, social science, and civic education. It is needed as additional material for all the basic competencies that are in the theme 8 sub-themes 1 including Indonesian Language and Cultural Arts and Crafts. Future research is expected to develop all basic competencies so that the material delivered is deeper and can measure all competencies on theme 8 sub-theme 1 .

\section{REFERENCES}

Anggarniastiti, T., Rosana, D., \& Setianingsih, W. (2017). the Development of Science Learning Device Based on Science Edutainment To Improve Student'S Learning Motivation and Cognitive Learning Achievement. Journal of Science Education Research, 1(1), 6-9. https://doi.org/10.21831/jser.v1i1.16183

Anggraheni, N. S., Hidayah, N., \& Shawmi, A. N. (2019). Developing Red-White Monopoly Games through Integrative Thematic Learning in the Primary School. Al Ibtida: Jurnal Pendidikan Guru MI, 6(1), 49. https://doi.org/10.24235/al.ibtida.snj.v6i1.3834

Ardani, R. A., \& Setyaningrum, W. (2018, September). Game-Based Edutainment Media using Guided Discovery Approach: What teachers say?.Journal of Physics: Conference Series, 1097(1), 1-9. https://doi.org/10.1088/1742-6596/1097/1/012101

Azman, F. N., Zaibon, S. B., \& Shiratuddin, N. (2014). Exploring Digital Comics as an Edutainment Tool: An Overview. Knowledge Management International Conference 2014 (KMICe2014), 12-15 August 2014, Langkawi, Malaysia.

Berman, E. T., Wiyono, A., Zakaria, A., \& Supriatno, S. (2019). Enhancing of Student Competency in Psychrometric Subjects Using the Edutainment Method. Advances in Social Science, Education and Humanities Research, 214, 54-58. https://doi.org/10.2991/ices-18.2019.14

Borg, W. R., \& Gall, M. D. (1983). Educational Research An Introduction. New York: Longman.

Budiarti, W. N., \& Haryanto, H. (2016). Pengembangan Media Komik Untuk Meningkatkan Motivasi Belajar Dan Keterampilan Membaca Pemahaman Siswa Kelas Iv. Jurnal Prima Edukasia, 4(2), 233. https://doi.org/10.21831/jpe.v4i2.6295

Cho, H. (2012). The Use Cartoons as Teaching a Tool in Middle School Mathematics. Seoul: ProQuest, UMI Dissertation Publishing.

Cirigliano, M. M. (2012). Exploring the Attitudes of Students Using an Edutainment Graphic Novel as a Supplement to Learning in the Classroom. Science Educator, 21(1), 29-36.

Dallacqua, A. K. (2020). Reading Comics Collaboratively and Challenging Literacy Norms. Literacy Research and Instruction, 59(2), 169-190. https://doi.org/10.1080/19388071.2019.1669746

Dallacqua, A. K., \& Peralta, L. R. (2019). Reading and (Re)writing Science Comics: A Study of Informational Texts. Reading Teacher, 73(1), 111-118. https://doi.org/10.1002/trtr.1801

Enteria, O., \& Casumpang, P. F. H. (2019). The Effectiveness of Developed Comic Strips as Intructional Materials in Teaching Specific Science Concepts. International Journal for Innovation Education and Research, 7(10), 876-882. https://doi.org/10.31686/ijier.vol7.iss10.1835

Handayani, M. (2018). Developing Thematic-Integrative Learning Module with ProblemBased Learning Model for Elementary School Students. Jurnal Prima Edukasia, 6(2), 
166-176. https://doi.org/10.21831/jpe.v6i2.14288

Hidayat, N., \& Rostikawati, T. (2018). The Effect of the Scientific Approach with Comic Intelligent Media Support on Students ' Science Competencies. Journal of Educational Review and Research, 1(1), 38-50. https://doi.org/http://dx.doi.org/10.26737/jerr.v1i1.507

Hwang, G. J., Yang, L. H., \& Wang, S. Y. (2013). A Concept Map-Embedded Educational Computer Game for Improving Students' Learning Performance in Natural Science Courses. Computers and Education, 69, 121-130. https://doi.org/10.1016/j.compedu.2013.07.008

Indaryati, I., \& Jailani, J. (2015). Pengembangan Media Komik Pembelajaran Matematika Meningkatkan Motivasi dan Prestasi Belajar Siswa Kelas V. Jurnal Prima Edukasia, 3(1), 84-96. https://doi.org/10.21831/JPE.V3I1.4067

Isa, W. M. W., Amin, M. A. M., Rozaimee, A., Idris, W. M. R. W., Rahim, N., \& Samaden, I. S. (2015). Conceptual framework of edutainment animated series for children: A pious story. ARPN Journal of Engineering and Applied Sciences, 10(3), 1106-1113.

Jee, B. D., \& Anggoro, F. K. (2012). Comic Cognition: Exploring the Potential Cognitive Impacts of Science Comics. Journal of Cognitive Education and Psychology, 11(2), 196-208. https://doi.org/10.1891/1945-8959.11.2.196

Kim, J., Chung, M. S., Jang, H. G., \& Chung, B. S. (2017). The use of educational comics in learning anatomy among multiple student groups. Anatomical Sciences Education, 10(1), 79-86. https://doi.org/10.1002/ase.1619

Kurniawati, A. A., Wahyuni, S., \& Putra, P. D. A. (2017). Utilizing of comic and Jember's local wisdom as integrated science learning materials. International Journal of Social Science and Humanity, 7(1), 47-50. https://doi.org/10.18178/ijssh.2017.7.1.793

Lin, S. F., Lin, H. shyang, Lee, L., \& Yore, L. D. (2015). Are Science Comics a Good Medium for Science Communication? The Case for Public Learning of Nanotechnology. International Journal of Science Education, Part B: Communication and Public Engagement, 5(3), 276-294. https://doi.org/10.1080/21548455.2014.941040

Morrison, T. G., Bryan, G., \& Chilcoat, G. W. (2002). Using student-generated comic books in the classroom. Journal of Adolescent and Adult Literacy, 45(8), 758-767. https://doi.org/10.2307/40012828

Munawwaroh, E. L., Priyono, B., \& Ningsih, M. R. (2018). The Influence of Science Comic Based Character Education on Understanding the Concept and Students' Environmental Caring Attitude on Global Warming Material. Journal of Biology Education, 7(2), 167-173. https://doi.org/10.15294/jbe.v7i2.24257

Muzumdar, J. (2016). An Overview of Comic Books as an Educational Tool and Implications for Pharmacy. INNOVATIONS in Pharmacy, 7(4), 1-10. https://doi.org/10.24926/iip.v7i4.463

Nugraheni, N. (2017). Penerapan Media Komik Pada Pembelajaran Matematika Di Sekolah Dasar. Refleksi Edukatika: Jurnal Ilmiah Kependidikan, 7(2), 111-117. https://doi.org/10.24176/re.v7i2.1587

Özdemir, Ertuğrul. (2017). Humor in elementary science: development and evaluation of comic strips about sound. International Electronic Journal of Elementary Education, 9(4), 837-850. 
Özdemir, Ertugrul, \& Eryilmaz, A. (2019). Comics in Science Teaching: A Case of Speech Balloon Completing Activity for Heat Related Concepts. Journal of Inquiry Based Activities (JIBA), 9(1), 37-51.

Putra, C. A. (2018). Enhanced Learning Outcomes Using Interactive Edutainment Learning Method. Proceedings International Conference Bksptis 2018, O(0), 219-224. Retrieved from http://jurnal.unissula.ac.id/index.php/bksptis/article/view/3576/2614

Rahayu, M. S. I., \& Kuswanto, H. (2020). Development of android-based comics integrated with scientific approach in physics learning. Journal of Physics: Conference Series, 1440(1). https://doi.org/10.1088/1742-6596/1440/1/012040

Resti, K. Y., \& Alizamar. (2019). Kreativitas Guru dalam Meningkatkan Hasil Belajar Siswa pada Pembelajaran Tematik Terpadu Kurikulum 2013 di Madrasah Ibtidaiyah Negeri Bayang Pesisir Selatan. Jurnal Basicedu, 3(2), 591-597. https://doi.org/https://doi.org/10.31004/basicedu.v3i2.43

Rosyida, A., Mustaji, M., \& Subroto, W. (2018). The Development of Contextual Teaching and Learn-ing-Based Comic as a Learning Media for Elementary School Students. Advances in Social Science, Education and Humanities Research, 173(Icei 2017), 1316. https://doi.org/10.2991/icei-17.2018.4

Sanaky, A. . (2013). Media Pembelajaran Interaktif-Inovatif. Yogyakarta: Kaukaban Dipantara.

Santrock, J. (2013). Life-Span Development (14th Editi). New York: McGraw-Hill Companies, Inc.

Saputro, H., \& Soeharto, S. (2015). Pengembangan Media Komik Berbasis Pendidikan Karakter pada Pembelajaran Tematik-Integratif Kelas IV SD. Jurnal Prima Edukasia, 3(1), 61-72. https://doi.org/10.1016/S0002-9378(15)30176-9

Shiang, R.-F. (2018). Embodied EFL Reading Activity: Let's Produce Comics. Reading in a Foreign Language, 30(1), 108-129.

Toh, Tin, L., Cheng, L. P., Ho, S. Y., Jiang, H., \& Lim, K. M. (2017). Use of comics to enhance students' learning for the development of the twenty-first century competencies in the mathematics classroom. Asia Pacific Journal of Education, 37(4), 437-452. https://doi.org/10.1080/02188791.2017.1339344

Vulte, M. J. (2013). Comic Books and Other Hooks: 21st Century Education. Bloomington: Author House.

Widyawati, A., \& Prodjosantoso, A. K. (2015). Pengembangan Media Komik Ipa Untuk Meningkatkan Motivasi Belajar Dan Karakter Peserta Didik Smp. Jurnal Inovasi Pendidikan IPA, 1(1), 24-35. https://doi.org/10.21831/jipi.v1i1.4529

Zagkotas, V. (2019). Are comic books appropriate for teaching History? Three suggestions for Greek Primary Education. Education 3-13, 47(3), 358-365. https://doi.org/10.1080/03004279.2018.1452955. 